\title{
Live Attenuated Measles Virus Vaccine
}

National Cancer Institute

\section{Source}

National Cancer Institute. Live Attenuated Measles Virus Vaccine. NCI Thesaurus. Code C82651.

A live, attenuated measles vaccine with potential antineoplastic activity. Upon subcutaneous administration, live attenuated measles virus vaccine may activate the immune system to mount a cytotoxic $T$-lymphocyte $(C T L)$ response ag ainst measlespositive tumor cells. Measles virus has been shown to be present in some non-small cell lung cancers. 